Research note

\title{
Partial albinism in Rhinelepis aspera from the Upper Paraná Basin, Brazil, with a review of albinism in South American freshwater fishes
}

\author{
Albinismo parcial en Rhinelepis aspera de la cuenca del Alto Paraná, Brasil, con una revisión \\ de albinismo en peces de agua dulce sudamericanos
}

\author{
André Batista Nobile ${ }^{a}$, Diogo Freitas-Souza ${ }^{a}$, Felipe Pontieri de Lima ${ }^{a}$, Aline Angelina Acosta ${ }^{b}$, \\ Reinaldo José Da Silva ${ }^{b, *}$ \\ a Laboratório de Biologia e Genética de Peixes, Universidade Estadual Paulista Júlio de Mesquita Filho, 18.618-970 Botucatu, SP, Brazil \\ ${ }^{\mathrm{b}}$ Laboratório de Parasitologia de Animais Silvestres, Universidade Estadual Paulista Júlio de Mesquita Filho, 18.618-970 Botucatu, SP, Brazil
}

Received 22 June 2015; accepted 10 February 2016

Available online 10 May 2016

\begin{abstract}
This study reports a case of partial albinism in Rhinelepis aspera from the Aguapeí River, Upper Paraná Basin, Brazil and provides a review of albinism cases in freshwater fishes from South America. The captured specimen has depigmentation throughout almost its entire body, with pigmented eyes and little dark spots on the dorsal and caudal fins. It is an adult male, and we suggest that due to the benthic habitat, it would be able to reach adult size, avoiding predators. The review shows a scarcity of this phenomenon in nature.

All Rights Reserved @ 2016 Universidad Nacional Autónoma de México, Instituto de Biología. This is an open access item distributed under the Creative Commons CC License BY-NC-ND 4.0.
\end{abstract}

Keywords: Albinism; Leucism; Fish; Loricariidae

\section{Resumen}

Este estudio registra un caso de albinismo parcial en Rhinelepis aspera del río Aguapeí, cuenca del Alto Paraná, Brasil y proporciona una revisión de los casos de albinismo en los peces de agua dulce de la América del Sur. El ejemplar capturado tiene despigmentación en casi todo el cuerpo, con los ojos pigmentados y pequeñas manchas oscuras en las aletas dorsal y caudal. Es un macho adulto y se sugiere que, debido al hábitat bentónico, el espécimen hubiera sido capaz de alcanzar el tamaño adulto, evitando a los depredadores. La revisión muestra una escasez de este fenómeno en la naturaleza.

Derechos Reservados (C) 2016 Universidad Nacional Autónoma de México, Instituto de Biología. Este es un artículo de acceso abierto distribuido bajo los términos de la Licencia Creative Commons CC BY-NC-ND 4.0.

Palabras clave: Albinismo; Leucismo; Peces; Loricariidae

Albinism is a pigmentation phenomenon characterized by the total loss of tegument and retina pigmentation, while individuals with partial albinism, also known as leucism, can have their eyes and some parts of their body pigmented (Reum, Paulsen, Pietsch, \& Parker-Stetter, 2008; Steven, 2002). These phenomena may

\footnotetext{
* Corresponding author.

E-mail address: reinaldo@ibb.unesp.br (R.J. Da Silva).

Peer Review under the responsibility of Universidad Nacional Autónoma de
} México. be related to environmental factors, such as exposure to heavy metals (Oliveira \& Foresti, 1996), heredity (Ueda, Ishinabe, \& Jeon, 2007), or artificial selection of albino individuals by aquarists (Brito \& Caramaschi, 2005). The aims of this study are to report a case of partial albinism in $R$. aspera and to present a review of natural cases of albinism in South American freshwater fishes.

The Neotropical ichthyofauna is the most diverse in the world, with about 6,000 species of freshwater fishes described (Reis, Kullander, \& Ferraris, 2003). However, albinism cases are rarely 


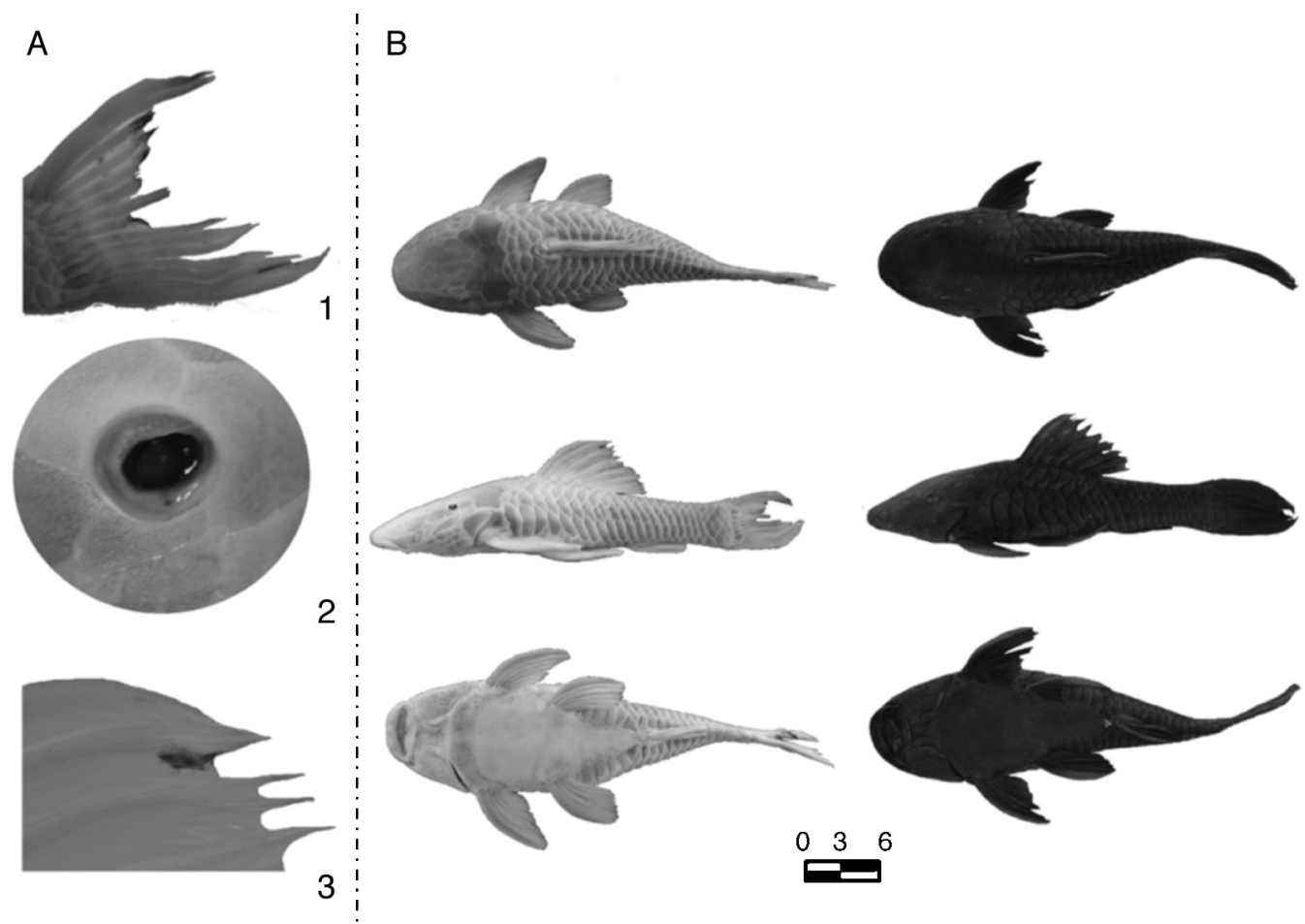

Figure 1. (A) Details of the pigmented area characteristics of the individual with partial albinism; (B) individual with partial albinism (left) and normal individual (right) sampled in the Upper Paraná Basin, São Paulo, Brazil. Scale in cm.

reported in the literature, especially those occurring naturally. Moreover, total or partial albinism is occasionally recorded in teleosts worldwide (Reum et al., 2008). Albinism is a phenomenon also found in populations of cavefishes, as reported for Astyanax mexicanus (Bilandžija, Parkhurst, \& Jeffery, 2013). In these cases all individuals of the populations present albinism, although this situation does not apply for this study.

Rhinelepis aspera Spix and Agassiz, 1829 (known as the black armored catfish) belongs to Loricariidae, an important family within the order Siluriformes, with approximately 800 species (Queiroz et al., 2013). Rhinelepis aspera is distributed along the Upper Paraná and São Francisco River Basins and is commonly used as a fishery resource. It inhabits areas with a rocky bottom and flowing waters, and exhibits iliophagous and reophilic behavior and reophilic behavior. Its size of first maturation is $25 \mathrm{~cm}$, and it reaches a maximum size of 54 cm (Agostinho, Gomes, Suzuki, \& Júlio, 2003; Costa, Okada, Agostinho, \& Gomes, 2012).

The specimen of $R$. aspera with partial albinism was collected with gillnets ( $7 \mathrm{~cm}$ between adjacent nodes) in November, 2014 in the Aguapeí River $\left(21^{\circ} 03^{\prime} 49.34^{\prime \prime} \mathrm{S} ; 51^{\circ} 45^{\prime} 13.72^{\prime \prime} \mathrm{W}\right)$, Upper Paraná Basin, Castilho Municipality, São Paulo, Brazil. The fish is deposited in the "Coleção do Laboratório de Biologia e Genética de Peixes", UNESP, Botucatu (Voucher: LBP-19697).

In order to assess possible morphometric differences, measurements were made following Armbruster (1998) for the individual with partial albinism and for 6 normal individuals (Voucher: LBP-12659 and LBP-7394) sampled in the same river basin.

The specimen sampled is an adult male with depigmentation in the body, except for the eyes and little dark spots on the dorsal and caudal fins, characteristic of partial albinism (Fig. 1A and B). The measurements taken for the individual with partial albinism and for the normal specimens were similar and in accordance with the range for this fish species (Table 1). Table 2 summarizes the rare cases of albinism or partial albinism in freshwater fishes from South America.

Previous records of pigmentation anomaly in $R$. aspera occurred 50 years ago (Luengo, 1965), suggesting how rare this phenomenon is, even though the species is commonly exploited as a fishery resource (Costa et al., 2012). Moreover, this is the first report of the occurrence of this genetic alteration in fish from the Aguapeí River.

This phenomenon is probably rare in South America, since there are only 16 reported cases in 14 species from more than 6,000 existing fish species (Reis et al., 2003). Most cases were described for the order Siluriformes, in representatives of the families Pimelodidae and Loricariidae. Pigmentation mutations are more common among nocturnal or cryptic species than among diurnal and non-cryptic species, given that the first are less susceptible to predation (Piorski \& Nunes, 2010), increasing the chances of reaching the adult stage (Reum et al., 2008). Thus, the benthonic habit of $R$. aspera may have helped the individual with partial albinism to reach sexual maturity.

The morphometric measurements of the individual with partial albinism showed no variations in relation to the normal specimens. Therefore, we conclude that despite the lack of pigmentation, the individual with partial albinism performed its biological functions normally.

The authors thank CNPq (307808/2014-9), Capes and Fapesp (2011/20186-6, 2012/22895-7) for the scholarship granted to the first four authors and CESP (Electric Company of São Paulo 
Table 1

Mean, standard deviation, and amplitude for normal individuals (Armbruster, 1998) and for the study area of the individual with partial albinism sampled in the Aguapeí River, Upper Paraná Basin, São Paulo, Brazil.

\begin{tabular}{|c|c|c|c|}
\hline \multirow[t]{2}{*}{ Measurements } & \multirow[t]{2}{*}{ Individual with partial albinism } & \multicolumn{2}{|c|}{ Normal individuals } \\
\hline & & Mean \pm SD & Range \\
\hline Standard length & 306.0 & $315.8 \pm 12.9$ & $293.0-329.0$ \\
\hline Predorsal length/SL & 43.9 & $44.1 \pm 2.6$ & $41.7-49.3$ \\
\hline Head length/SL & 35.6 & $35.2 \pm 1.0$ & $33.9-36.4$ \\
\hline Orbit diameter/SL & 3.7 & $3.5 \pm 0.3$ & $3.1-3.9$ \\
\hline Snout length/SL & 22.2 & $22.4 \pm 0.5$ & $21.9-23.3$ \\
\hline Interorbital width/SL & 18.4 & $19.4 \pm 0.6$ & $18.2-20.1$ \\
\hline Thorax length/SL & 18.6 & $19.5 \pm 0.5$ & $18.8-20.1$ \\
\hline Pectoral-spine length/SL & 26.0 & $24.0 \pm 1.8$ & $21.2-26.8$ \\
\hline Abdomen length/SL & 28.3 & $26.3 \pm 0.9$ & $25.5-27.7$ \\
\hline Pelvic-spine length/SL & 22.9 & $22.2 \pm 1.8$ & $19.0-24.2$ \\
\hline Postanal length/SL & 27.5 & $22.4 \pm 1.2$ & $21.0-24.5$ \\
\hline Anal-fin length/SL & 17.7 & $16.8 \pm 1.2$ & $15.2-18.8$ \\
\hline Caudal depth/SL & 13.0 & $12.6 \pm 0.3$ & $12.2-13.1$ \\
\hline Dorsal-caudal length/S & 29.0 & $32.6 \pm 0.9$ & $31.3-33.7$ \\
\hline Dorsal-fin length/SL & 21.5 & $21.4 \pm 0.6$ & $20.5-22.1$ \\
\hline Dorsal-spine length/SL & 23.2 & $19.6 \pm 0.9$ & $18.0-20.7$ \\
\hline Head depth/SL & 19.2 & $18.2 \pm 1.3$ & $15.4-19.4$ \\
\hline Width at anal fin/SL & 16.9 & $15.3 \pm 2.5$ & $12.6-20.0$ \\
\hline Cleithral width/SL & 31.4 & $31.4 \pm 1.6$ & $28.2-33.0$ \\
\hline
\end{tabular}

Table 2

List of albinism and partial albinism cases reported in freshwater fishes from the Neotropical region.

\begin{tabular}{|c|c|c|c|c|}
\hline Order & Family & Species & Locality & Reference \\
\hline Characiformes & Erythrinidae & Hoplias malabaricus (Bloch 1794) & Brazil & Silva, Araújo, and Bicudo (2013) \\
\hline Gymnotiformes & Gymnotidae & Gymnotus carapo Linnaeus 1758 & Brazil & $\begin{array}{l}\text { Campos-da Paz and Caramaschi } \\
\text { (1994) }\end{array}$ \\
\hline Lepidosireniformes & Lepidosirenidae & Lepidosiren paradoxa Fitzinger 1837 & Argentina & Azpelicueta and Braga (1984) \\
\hline \multirow{8}{*}{ Siluriformes } & \multirow{2}{*}{ Callichthyidae } & Corydoras paleatus (Jenyns 1842) & Brazil & Fach (1963) \\
\hline & & Megalechis thoracata (Valenciennes 1840) & Argentina & $\begin{array}{l}\text { Taberner, Fernández-Santos, } \\
\text { and Castelli (1976) }\end{array}$ \\
\hline & Doradidae & Oxydoras knerii Bleeker 1862 & Argentina & Del Barco and Panattieri (1980) \\
\hline & \multirow[t]{3}{*}{ Loriicaridae } & Rhinelepis aspera Spix \& Agassiz & Uruguay & Luengo (1965) \\
\hline & & Hypostomus plecostomus (Linnaeus 1758) & Tropical South America & Burgess (1989) \\
\hline & & Schizolecis guntheri (Miranda Ribeiro 1918) & Brazil & Brito and Caramaschi (2005) \\
\hline & \multirow[t]{2}{*}{ Pimelodidae } & Zungaro zungaro (Humboldt 1821) & Argentina & Taberner et al. (1976) \\
\hline & & Rhandella minuta (Lütken) & Brazil & Sazima and Pombal (1986) \\
\hline
\end{tabular}

State) for financial support to carry out the project. This study was developed according to the Brazilian national research laws.

\section{References}

Agostinho, A. A., Gomes, L. C., Suzuki, H. I., \& Júlio, H. F., Jr. (2003). Migratory fishes of the Upper Paraná River Basin, Brazil. In J. Carolsfeld, C. R. Harvey, \& A. Baer (Eds.), Migratory fishes of South America: biology, fisheries and conservation status (pp. 19-98). Ottawa: World Fisheries Trust.

Armbruster, J. W. (1998). Phylogenetic relationships of the suckermouth armored catfishes of the Rhinelepis group (Loricariidae: Hypostominae). Copeia, 3, 620-636.

Azpelicueta, M. M., \& Braga, L. (1984). Albinismo en Lepidosiren paradoxa Fitzinger, 1837 (Osteichthyes, Dipnoi, Lepidosirenidae). Neotropica, 30, $75-78$.
Bilandžija, Parkhurst, \& Jeffery, W. R. (2013). A potential benefit of albinism in Astyanax cavefish: downregulation of the oca 2 gene increases tyrosine and catecholamine levels as an alternative to melanin synthesis. PLOS ONE, 8, e80823.

Brito, M. F. G., \& Caramaschi, E. P. (2005). An albino armored catfish Schizolecis guntheri (Siluriformes: Loricariidae) from an Atlantic Forest coastal basin. Neotropical Ichthyology, 3, 123-125.

Burgess, W. E. (1989). An atlas of freshwater and marine catfishes: a preliminary survey of the Siluriformes. New Jersey: TFH Publications.

Campos-da Paz, R., \& Caramaschi, E. P. (1994). First record of albinism in a gymnotiform fish (Teleostei: Ostariophysi). Ichthyological Exploration of Freshwaters, 5, 1-4.

Costa, R. S., Okada, E. K., Agostinho, A. A., \& Gomes, L. C. (2012). Variação temporal no rendimento e composição específica da pesca artesanal do Alto rio Paraná, PR - Brasil: os efeitos crônicos dos barramentos. Boletim do Instituto de Pesca de São Paulo, 38, 199-213. 
Del Barco, D. M., \& Panattieri, A. E. (1980). Un caso de albinismo en armado chancho Oxidoras kneri Bleeker 1862. Pisces, Doradidae. Comunicaciones del Museo Provincial de Ciencias Naturales Florentino Ameghino. Zoologï̈a, 9, 9-10

Fach, D. (1963). Albinotische Corydoras paleatus. Aquarien Terrarien Zeitschriften, 16, 225-227.

Luengo, J. A. (1965). Un caso de albinismo en Rhinelepis aspera Agassiz del Uruguay (Pisces, Loricariidae). Neotropica, 11, 51-52.

Oliveira, C., \& Foresti, F. (1996). Albinism in the banded knifefish, Gymnotus carapo. TFH Magazine, 44, 92-96.

Piorski, N. I., \& Nunes, J. L. S. (2010). A case of albinism in Batrachoides surinamensis (Batrachoidiformes: Batrachoididae) from northeastern Brazil. Marine Biodiversity Records, 3, e99.

Queiroz, L. J., Torrente-Vilara, G., Ohara, W. M., Pires, T. H. S., Zuanon, J., \& Doria, C. R. C. (2013). Peixes do Rio Madeira. São Paulo: Dialeto.

Reis, R. E., Kullander, S. O., \& Ferraris, C. J., Jr. (2003). Check list of the freshwater fishes of South and Central America. Porto Alegre, Brasil: Pontifícia Universidade Católica do Rio Grande do Sul.
Reum, J. C. P., Paulsen, C. E., Pietsch, T. W., \& Parker-Stetter, S. L. (2008). First record of an albino chimaeriform fish, Hydrolagus colliei. Northwestern Naturalist, 89, 60-62.

Sazima, I., \& Pombal, J. P. (1986). Um albino de Rhamdella minuta, com notas sobre comportamento (Osteichthyes, Pimelodidae). Revista Brasileira de Biologia, 46, 377-438

Silva, T. R. M., Araújo, T. A. T., \& Bicudo, A. J. A. (2013). First report of albinism in trahira Hoplias malabaricus from Brazil. Boletim do Instituto de Pesca de São Paulo, 39, 457-460.

Steven, C. (2002). First report of albinism in the white-spotted bamboo shark, Chiloscyllium plagiosum (Orectolobiformes: Hemiscyllidae) with a review of reported color aberrations in elasmobranchs. Zoo Biology, 21, 519-524.

Taberner, R., Fernández-Santos, J. O., \& Castelli, J. O. (1976). Un manguruyú albino Paulicea luetkeni (Steindachner 1876) Eigenmann 1910. Physis B, $35,121-123$

Ueda, T., Ishinabe, T., \& Jeon, S. R. (2007). Establishment of an albino strain of the bitterling Tanakia signifer (Pisces, Cyprinidae). Journal of Heredity, 98, 277-279 